\title{
Nutritional efficiency in phosphorus of arabica coffee genotypes
}

\author{
Diego Júnior Martins Vilela ${ }^{1}$ (D), Larissa Sousa Coelho ${ }^{(1 D}$, Douglas Ramos Guelfi Silva ${ }^{3}$ (D), \\ Gladyston Rodrigues Carvalho ${ }^{4}$ (i) , Cesar Elias Botelho ${ }^{4}$ (D), André Dominghetti Ferreira ${ }^{5}$ (iD
}

\author{
${ }^{1}$ Empresa de Pesquisa Agropecuária de Minas Gerais/EPAMIG, Epamig Oeste, Patrocínio, MG, Brasil \\ ${ }^{2}$ Universidade Federal de Lavras/UFLA, Departamento de Agricultura/DAG, Lavras, MG, Brasil \\ ${ }^{3}$ Universidade Federal de Lavras/UFLA, Departamento de Ciência do Solo/DCS, Lavras, MG, Brasil \\ ${ }^{4}$ Empresa de Pesquisa Agropecuária de Minas Gerais/EPAMIG, Epamig Sul Lavras, Lavras, MG, Brasil \\ ${ }^{5}$ Empresa Brasileira de Pesquisa Agropecuária/EMBRAPA, Embrapa Café, Brasília, DF, Brasil \\ Contact authors: diegovilela26@yahoo.com.br, diego.vilela@epamig.br, larissacoelhoagro@gmail.com, douglasguelfi@ufla.br, grodriguescarvalho@gmail.com, \\ cesarbotelho@epamig.br, andre.dominghetti@embrapa.br \\ Received in October 19, 2020 and approved February 21, 2021
}

\section{ABSTRACT}

Nutritional efficiency is a term used to characterize plants in their capacity to uptake and use nutrients, being related to the efficiency of uptake, translocation, and utilization of nutrients. Different coffee genotypes are expected to exhibit variability in their nutritional efficiency. This work aimed to evaluate the phosphorus nutritional efficiency in arabica coffee genotypes. The experiment was carried out in a greenhouse of the Empresa de Pesquisa Agropecuária de Minas Gerais (EPAMIG), located in the municipality of Lavras - Minas Gerais, Brazil. The experimental design was a randomized complete block design, in a 10x2 factorial scheme (10 arabica coffee genotypes and two dosages of phosphate fertilization), with four replicates. Each experimental plot consisted of one pot with ten liters of soil, with one plant. The cultivars Catiguá MG2, MGS Ametista and Sarchimor MG 8840 are neither efficient nor responsive to phosphate fertilization. Progeny H 6-47-10 pl. 3 and the cultivar Catuaí Vermelho IAC 144 are not efficient but are responsive to phosphate fertilization. The cultivars Paraíso MG H 419-1, Topázio MG 1190 and MGS Paraíso 2 are efficient but are not responsive to phosphate fertilization. The cultivars Bourbon Amarelo IAC J10 and MGS Aranãs are efficient and responsive to phosphate fertilization.

Index terms: Coffea arabica; Cultivars; Mineral nutrition.

\section{INTRODUCTION}

The coffee tree, like any plant, needs several nutrients to complete its vegetative and reproductive cycle. Vegetable species show variability in their nutritional requirement, both qualitatively and quantitatively, and, in addition, they show this variability even within the species itself, in which different cultivars may have specific nutritional requirements.

Phosphorus is a fundamental nutrient for the development of plants, performing several functions, like the constitution of nucleotides (nucleic acids), actively participates in the processes of energy storage and transfer (ATP) and of phospholipid membranes. Its use as a fertilizer requires specific care in relation to its dynamics in the soil and the demand of plants. As a highly precious and scarce mineral resource, the search for a more rational, efficient, and sustainable use of phosphate fertilizers, both economically and environmentally, is highly desired.

New coffee cultivars with the most diverse desirable agronomic characteristics, such as resistance to pests and diseases, tolerance to abiotic stresses, among others, are being available year by year to coffee growers. These cultivars are increasingly productive, demanding more nutrients. In addition, coffee growing has been expanding to soils of low natural fertility, requiring inputs from correctives and fertilizers, thus requiring a better understanding of the interaction of these new cultivars with their nutrition, to avoid nutritional deficiencies.
Informations regarding the mineral nutrition of coffee are found in the literature, such as questions regarding the uptake, transport, and redistribution of nutrients, with the possibility of improving or selecting more efficient cultivars regarding the use of nutrients. Nowadays, however, due to the most diverse existing cultivation conditions and with new cultivars available to farmers, further studies are needed to measure the nutritional efficiency of these new cultivars.

In a large study, Amaral et al. (2011) tested the nutritional requirements of $\mathrm{N}, \mathrm{P}, \mathrm{K}, \mathrm{Ca}, \mathrm{Mg}, \mathrm{S}, \mathrm{B}, \mathrm{Cu}$ and $\mathrm{Zn}$ in root and aerial part production among different coffee cultivars (Acaiá IAC 474-19, Icatu Amarelo IAC 3282, Rubi MG 1192 and Catuaí Vermelho IAC 99) and three levels of fertilization (low, normal, and high), concluded that the efficiency of use of nutrients for root production and use of nutrients by the aerial part of coffee trees was different between the cultivars. Tomaz et al. (2011) studied the efficiency of uptake and use of B, Zn, $\mathrm{Cu}$ and $\mathrm{Mn}$ in grafted coffee seedlings, where four genotypes of Coffea arabica (Catuaí Vermelho IAC 15, Oeiras MG 6851 and the progenies H 419- 10-3-4-4 and H 514-5-5-3) and as rootstock five progenies of Coffea canephora cv. Conilon (ES 21, ES 36, ES 26, ES 23 and ES 38), and the nutritional efficiency of the plants varied according to the graft/rootstock combination. Neto et al. (2016) studied the nutritional efficiency in phosphorus in 21 cultivars of Coffea arabica and 4 cultivars of Coffea canephora, where results were found in plant growth, highly reduced under $\mathrm{P}$ deprivation; the 
concentration of $\mathrm{P}$ in the dry mass was higher in the cultivars of Coffea canephora and the young leaves accumulated more $\mathrm{P}$ than any other tissues.

Different coffee genotypes are expected to show variability in their nutritional efficiency. Sources of phosphate fertilizers are increasingly expensive and scarce, so more efficient and sustainable use of this resource is required. More nutritionally efficient genotypes are highly desired, given the growing demand for food and the need for more sustainable forms of production. Thus, this work aimed to evaluate the nutritional efficiency in phosphorus of arabica coffee genotypes.

\section{MATERIAL AND METHODS}

\subsection{Characterization of the experiment}

The experiment was carried out in a greenhouse of the Agricultural Research Corporation of Minas Gerais (EPAMIG), located in the municipality of Lavras - MG, at latitude $21^{\circ} 14^{\prime} 30^{\prime \prime}$ South and longitude $45^{\circ} 00^{\prime} 10^{\prime \prime}$ West and altitude of $918.8 \mathrm{~m}$. The average temperature and relative humidity of the greenhouse in the experimental period were $23{ }^{\circ} \mathrm{C}$ and $65 \%$, respectively.

The soil used in the experiment was classified as dystrophic red oxisol (Empresa Brasileira de Pesquisa Agropecuária - EMBRAPA, 2018). The soil was sieved and homogenized before any treatments were applied. Liming was performed to correct soil acidity and increase base saturation to $70 \%$. The pots were wetted twice a week and remained for 30 days in the incubation period, for limestone reaction. The seedlings used in the experiment were produced with commercial substrate Plantmax ${ }^{\circledR}$ and transplanted when they presented three pairs of leaves.

The experimental design was a randomized block, in a 10x2 factorial scheme (10 coffee genotypes and two phosphate fertilizer doses), with four replicates. Each experimental plot consisted of a pot with ten liters of soil, with one plant. The genotypes used were Paraíso MG H 419-1, Catuaí Vermelho IAC 144, Catiguá MG2, Topázio MG 1190, Bourbon Amarelo IAC J10, Sarchimor MG 8840, MGS Aranãs, MGS Ametista, MGS Paraíso 2 and the progeny $\mathrm{H}$ 6-47-10 pl. 3. The two dosages of phosphate fertilization were the zero dose (without phosphate fertilization) and the dose of $200 \mathrm{mg} \mathrm{dm}^{-3}$ of $\mathrm{P}$ per pot. Phosphate fertilization in the experimental plots that received it was carried out in a single application, one week before transplanting the seedlings into the pots. In addition, each pot received $300 \mathrm{mg} \mathrm{dm}^{-3}$ of $\mathrm{N}$ and $200 \mathrm{mg} \mathrm{dm}^{-3}$ of $\mathrm{K}$, parted into five times, applied every thirty days, with the first application made on the date of transplanting the seedlings to the pots. The dosages used were adapted from Novais, Neves and Barros (1991). All fertilizations were made using nutritive solutions. The pots were irrigated 3-4 times a week, varying with the growth of the plants over the months, and the volume of water added was calculated so that there was no overflow.

The experiment remained for eight months in a greenhouse. Then, it was disassembled and samples of soil and plant material (roots and aerial part) from each plot were collected for analysis.

The chemical and physical properties of the soil used in the experiment, before receiving any of the treatments, were: $\mathrm{pH}=5,80$; P-Mehlich-1 $=0.28 \mathrm{mg} \mathrm{dm}^{-3}$; P-resin $=2.27 \mathrm{mg} \mathrm{dm}^{-3}$; P-remaining $=1.52 \mathrm{mg} \mathrm{L}^{-1} ; \mathrm{K}=22.0 \mathrm{mg} \mathrm{dm}{ }^{-3} ; \mathrm{Ca}^{2+}=0.30$ $\mathrm{cmol}_{\mathrm{c}} \mathrm{dm}^{-3} ; \mathrm{Mg}^{2+}=0.10 \mathrm{cmol}_{\mathrm{c}} \mathrm{dm}^{-3} ; \mathrm{S}^{-\mathrm{SO}_{4}}=7.82 \mathrm{mg} \mathrm{dm}{ }^{-3}$; $\mathrm{Cu}^{2+}=0.57 \mathrm{mg} \mathrm{dm}{ }^{-3} ; \mathrm{B}=0.56 \mathrm{mg} \mathrm{dm}{ }^{-3} ; \mathrm{Zn}^{2+}=0.59 \mathrm{mg} \mathrm{dm}{ }^{-3}$; $\mathrm{Fe}^{2+}=34.67 \mathrm{mg} \mathrm{dm}{ }^{-3} ; \mathrm{Mn}^{2+}=4.30 \mathrm{mg} \mathrm{dm}^{-3} ; \mathrm{Al}^{3+}=0.00 \mathrm{cmol}_{\mathrm{c}}$ $\mathrm{dm}^{-3}$; potential acidity $(\mathrm{H}+\mathrm{Al})=0.84 \mathrm{cmol}_{\mathrm{c}} \mathrm{dm}^{-3}$; sum of bases $(\mathrm{SB})=0.46 \mathrm{cmol}_{\mathrm{c}} \mathrm{dm}^{-3}$; effective cation exchange capacity $(\mathrm{t})$ $=0.46 \mathrm{cmol}_{\mathrm{c}} \mathrm{dm}^{-3}$; total cation exchange capacity $(\mathrm{T})=1.30$ $\mathrm{cmol}_{\mathrm{c}} \mathrm{dm}^{-3}$; aluminum saturation $(\mathrm{m})=0.00 \%$; base saturation (V) $=35.11 \%$; organic matter $=0.40 \mathrm{~g} \mathrm{dm}^{-3}$; sand $=18 \%$; silt $=15 \%$; clay $=67 \%$. The extractors used were: $\mathrm{pH}=$ water; P-Mehlich, $\mathrm{K}, \mathrm{Fe}, \mathrm{Zn}, \mathrm{Mn}$ and $\mathrm{Cu}=$ extractor Mehlich-1; $\mathrm{P}-\mathrm{Resin}=$ extractor resin; $\mathrm{Ca}^{2+}, \mathrm{Mg}^{2+}$ e $\mathrm{Al}^{3+}=$ extractor $\mathrm{KCl}(1$

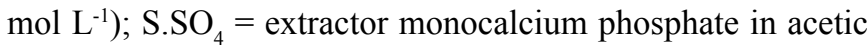
acid; $(\mathrm{H}+\mathrm{Al})=$ extractor SMP; organic matter: oxidation with $\mathrm{Na}_{2} \mathrm{Cr}_{2} \mathrm{O}_{7} 4 \mathrm{~N}+\mathrm{H}_{2} \mathrm{SO}_{4} 10 \mathrm{~N} ; \mathrm{B}=$ extractor hot water-soluble.

\subsection{Evaluations}

To determine the dry mass, each part of the plant (root, stem and leaves) was properly separated and processed. All parts were dried in a forced air oven at $65^{\circ} \mathrm{C}$ until constant weight was obtained. After drying, the samples were weighed on a precision scale, then ground in a Wiley mill and stored to determine their phosphorus concentration. Aerial part dry mass (MSPA) and total dry mass (MST) were calculated as follows: a) dry mass of the aerial part (MSPA): obtained by adding the dry mass of the leaves and stem; b) total dry mass (MST): obtained by adding the dry mass of the roots, stem and leaves. From the results of the total dry mass (MST) for each treatment in each repetition, the total dry mass with phosphate fertilization and total dry mass without phosphate fertilization (MSTAP) were also calculated separately.

To determine the concentration of phosphorus available in the soil (PDI), the Mehlich-1 extractor was used, according to the methodology described by Novais and Smith (1999). The remaining phosphorus in the soil (PRM) was obtained according to Alvarez et al. (2000). Also, phosphorus in the soil was determined by the "ion exchange resin" (PRS) extractor, according to the methodology proposed by Van Raij and Quaggio (1983). The phosphorus content in the roots (PRZ) and phosphorus content in the aerial part (stem and leaves) of the plant (PPA) were determined by nitroperchloric digestion, according to Sarruge and Haag (1974). The levels of P in 
both soil and plant tissues were determined by colorimetry (spectrophotometry), according to Tedesco et al. (1995).

Also, the accumulation of phosphorus in the different parts of the plant was calculated. Accumulations were calculated as follows: a) root phosphorus accumulation (APRZ): [root phosphorus content (PRZ) x dry mass of the roots $(\mathrm{MSR})]$; b) aerial part phosphorus accumulation (APPA): [phosphorus content in the aerial part (PPA) $\mathrm{x}$ dry mass of the aerial part (MSPA)]; c) plant phosphorus accumulation (APPL): [accumulation of phosphorus in the root (APRZ) + accumulation of phosphorus in the aerial part (APPA)]. From the results of the plant phosphorus accumulation (APPL) for each treatment in each repetition, the accumulation of phosphorus in the plant with phosphate fertilization and the accumulation of phosphorus in the plant without phosphate fertilization were also calculated separately.

Regarding the nutritional efficiency indexes, they were calculated as follows: a) phosphorus uptake efficiency (EAP): (plant phosphorus accumulation / dry mass of the roots), according to Swiader, Chyan and Freiji (1994); b) phosphorus translocation efficiency (ETP): [(aerial part phosphorus accumulation / plant phosphorus accumulation)] x 100], according to Li, Mckeand and Allen (1991); c) root phosphorus use efficiency (EUPRZ): (dry mass of the roots ${ }^{2}$ / plant phosphorus accumulation), according to Siddiqi and Glass (1981); d) aerial part phosphorus use efficiency (EUPPA): (dry mass of the aerial part ${ }^{2} /$ plant phosphorus accumulation), according to Siddiqi and Glass (1981); e) plant phosphorus use efficiency (EUPPL): (total dry mass ${ }^{2}$ / plant phosphorus accumulation), according to Siddiqi and Glass (1981); f) agronomic phosphorus use efficiency (EAUP): [(total dry mass with phosphate fertilization total dry mass without phosphate fertilization) / (plant phosphorus accumulation with phosphate fertilization - plant phosphorus accumulation without phosphate fertilization)], according to the adapted methodology of Oliveira et al. (1987).

With the agronomic phosphorus use efficiency (EAUP) and with the total dry mass without phosphate fertilization (MSTAP), and as a way to separate the coffee genotypes in terms of their response and efficiency to phosphate fertilization, a graph was created, according to what was proposed by Gerloff (1977), where there are genotypes that were classified as: a) efficient and responsive (ER); b) efficient and unresponsive (ENR); c) inefficient and responsive (NER); d) inefficient and unresponsive (NENR). The general mean, both of the agronomic phosphorus use efficiency (EAUP), and of the total dry mass without phosphate fertilization (MSTAP), were the parameters used to trace the reference lines, or cut lines, for the classification of the genotypes regarding their efficiency and responsiveness.

\subsection{Statistical analyzes}

The data obtained in the experiment were subjected to analysis of variance ( $\mathrm{F}$ test). The mean were compared using the Scott-Knott cluster test, at a significance level of 5\%. Also, a multivariate principal components analysis (PCA) was carried out, adopting the criterion of at least $70 \%$ of the total variation of the data accumulated in the first two components (Ferreira, 2011). The statistical software used was GENES (Cruz, 2013).

\section{RESULTS}

The summary of the analysis of variance of the evaluated characters is shown in Table 1. The interaction between genotypes (G) and dose (D) was not significant. The factors analyzed in isolation were significant for some characteristics.

Table 1: Summary of the analysis of variance of dry mass of the roots (MSR), dry mass of the aerial part (MSPA), total dry mass (MST), root phosphorus accumulation (APRZ), aerial part phosphorus accumulation (APPA), plant phosphorus accumulation (APPL), phosphorus available in the soil (PDI), phosphorus resin (PRS), remaining phosphorus in the soil (PRM), phosphorus content in the roots (PRZ), phosphorus content in the aerial part (PPA), phosphorus uptake efficiency (EAP), phosphorus translocation efficiency (ETP), root phosphorus use efficiency (EUPRZ), aerial part phosphorus use efficiency (EUPPA) and plant phosphorus use efficiency (EUPPL) of arabica coffee genotypes under absence or presence of phosphate fertilization.

\begin{tabular}{ccccc}
\hline \multicolumn{5}{c}{ Variation sources } \\
\hline Variables & Genotypes $(\mathrm{G})$ & Doses $(\mathrm{D})$ & $\mathrm{G}^{*} \mathrm{D}$ & $\mathrm{CV}(\%)$ \\
\hline MSR & $181.59^{*}$ & $1557.61^{*}$ & $68.99^{\text {ns }}$ & 26.76 \\
MSPA & $255.56^{*}$ & $848.90^{*}$ & $18.09^{\text {ns }}$ & 14.36 \\
MST & $681.76^{*}$ & $4706.31^{*}$ & $109.89^{\text {ns }}$ & 14.99 \\
APRZ & $66.72^{*}$ & $1693.07^{*}$ & $28.37^{\text {ns }}$ & 29.47 \\
APPA & $274.64^{\text {ns }}$ & $13844.84^{*}$ & $145.90^{\text {ns }}$ & 44.16 \\
APPL & $508.68^{*}$ & $25219.20^{*}$ & $154.38^{\text {ns }}$ & 30.53 \\
PDI & $0.90^{\text {ns }}$ & $159.64^{*}$ & $0.82^{\text {ns }}$ & 58.69 \\
PRS & $24.86^{\text {ns }}$ & $6450.69^{*}$ & $23.44^{\text {ns }}$ & 36.98 \\
PRM & $2.03^{\text {ns }}$ & $13.19^{*}$ & $1.04^{\text {ns }}$ & 27.55 \\
PRZ & $0.07^{*}$ & $0.61^{*}$ & $0.03^{\text {ns }}$ & 22.68 \\
PPA & $0.09^{\text {ns }}$ & $7.50^{*}$ & $0.14^{\text {ns }}$ & 42.89 \\
EAP & $1.38^{\text {ns }}$ & $17.46^{*}$ & $1.07^{\text {ns }}$ & 46.45 \\
ETP & $154.26^{\text {ns }}$ & $331.86^{\text {ns }}$ & $136.42^{\text {ns }}$ & 16.05 \\
EUPRZ & $197.43^{*}$ & $6.85^{\text {ns }}$ & $104.38^{\text {ns }}$ & 54.82 \\
EUPPA & $182.26^{*}$ & $1419.86^{*}$ & $45.57^{\text {ns }}$ & 37.49 \\
EUPPL & $1709.31^{*}$ & $3650.80^{*}$ & $924.63^{\text {ns }}$ & 36.08 \\
\hline
\end{tabular}

: significant at $5 \%$ significance by the $\mathrm{F}$ test; ${ }^{\text {ns: }}$ not significant; $\mathrm{CV}$ : variation coeficient. 
Regarding the dose factor, since there are only two levels of this factor, two groups were formed. Phosphate fertilization significantly influenced the results, showing superior behavior when compared to where there was no phosphate fertilization. The exception was only in the aerial part phosphorus use efficiency and in the plant phosphorus use efficiency, where the interpretation for these parameters is the opposite. In percentage value, the increase was: dry mass of the roots $(45.2 \%)$, dry mass of the aerial part $(22.3 \%)$, total dry mass $(31.5 \%)$, root phosphorus accumulation $(85.9 \%)$, aerial part phosphorus accumulation (123.8\%), plant phosphorus accumulation (111.1\%), phosphorus available in the soil $(542.3 \%)$, phosphorus resin $(621.5 \%)$, remaining phosphorus in the soil $(21.7 \%)$, phosphorus content in the plant root $(32.7 \%)$ and phosphorus content in the aerial part of the plant $(83.6 \%)$ (Table 2).

Table 2: Mean of dry mass of the roots (MSR), dry mass of the aerial part (MSPA), total dry mass (MST), root phosphorus accumulation (APRZ), aerial part phosphorus accumulation (APPA), plant phosphorus accumulation (APPL), phosphorus available in the soil (PDI), phosphorus resin (PRS), remaining phosphorus in the soil (PRM), phosphorus content in the roots (PRZ), phosphorus content in the aerial part (PPA), phosphorus uptake efficiency (EAP), aerial part phosphorus use efficiency (EUPPA) and plant phosphorus use efficiency (EUPPL) under absence or presence of phosphate fertilization.

\begin{tabular}{cccc}
\hline Feature & $-\mathrm{P}$ & $+\mathrm{P}$ & $\%$ increase \\
\hline MSR $(\mathrm{g})$ & $19.52 \mathrm{~b}$ & $28.34 \mathrm{a}$ & $45.2^{*}$ \\
MSPA $(\mathrm{g})$ & $29.20 \mathrm{~b}$ & $35.72 \mathrm{a}$ & $22.3^{*}$ \\
MST $(\mathrm{g})$ & $48.72 \mathrm{~b}$ & $64.06 \mathrm{a}$ & $31.5^{*}$ \\
APRZ $(\mathrm{mg})$ & $10.71 \mathrm{~b}$ & $19.91 \mathrm{a}$ & $85.9^{*}$ \\
APPA $(\mathrm{mg})$ & $21.25 \mathrm{~b}$ & $47.56 \mathrm{a}$ & $123.8^{*}$ \\
APPL $\left(\mathrm{mg}^{-}\right)$ & $31.96 \mathrm{~b}$ & $67.47 \mathrm{a}$ & $111.1^{*}$ \\
PDI $\left(\mathrm{mg} \mathrm{dm}^{-3}\right)$ & $0.52 \mathrm{~b}$ & $3.34 \mathrm{a}$ & $542.3^{*}$ \\
PRS $\left(\mathrm{mg} \mathrm{dm}^{-3}\right)$ & $2.89 \mathrm{~b}$ & $20.85 \mathrm{a}$ & $621.5^{*}$ \\
PRM $\left(\mathrm{mg} \mathrm{L}^{-1}\right)$ & $3.78 \mathrm{~b}$ & $4.60 \mathrm{a}$ & $21.7^{*}$ \\
PRZ $\left(\mathrm{g} \mathrm{kg}^{-1}\right)$ & $0.55 \mathrm{~b}$ & $0.73 \mathrm{a}$ & $32.7^{*}$ \\
PPA $\left(\mathrm{g} \mathrm{kg}^{-1}\right)$ & $0.73 \mathrm{~b}$ & $1.34 \mathrm{a}$ & $83.6^{*}$ \\
EAP $\left(\mathrm{mg} \mathrm{g}^{-1}\right)$ & $1.71 \mathrm{~b}$ & $2.65 \mathrm{a}$ & $55.0^{*}$ \\
EUPPA $\left(\mathrm{g}^{2} \mathrm{mg}^{-1}\right)$ & $28.75 \mathrm{a}$ & $20.32 \mathrm{~b}$ & $41.5^{* *}$ \\
EUPPL $\left(\mathrm{g}^{2} \mathrm{mg}^{-1}\right)$ & $80.12 \mathrm{a}$ & $66.61 \mathrm{~b}$ & $20.3^{* *}$ \\
\hline
\end{tabular}

Mean followed by the same letter on the line do not differ statistically from each other, at $5 \%$ significance, by the Scott-Knott cluster test. "The percentage of increase (\% increase) refers to where there was phosphate fertilization $(+P)$ over where there was no phosphate fertilization (-P). "The percentage of increase (\% increase) of EUPPA and EUPPL refers to where there was no phosphate fertilization $(-P)$ over where there was phosphate fertilization $(+\mathrm{P})$.
For phosphorus uptake efficiency, the highest efficiency was observed where there was phosphate fertilization, with the nutrient being more readily available to be uptake by the roots of the coffee tree and accumulated throughout the plant. Also, the dry mass of the roots was greater where there was phosphate fertilization, which reinforces this result obtained. The percentage of increase was $55 \%$, when compared between where there was phosphate fertilization versus where there was not (Table 2). As for the aerial part phosphorus use efficiency and plant phosphorus use efficiency, the highest values were observed where there was no phosphate fertilization, signaling that the plants were more efficient in producing dry mass even thanks to the low availability of phosphorus. The percentage of increase between where there was no phosphate fertilization where there was $41.5 \%$ and $20.3 \%$, respectively (Table 2 ).

Table 3 shows the mean of dry mass of the roots, dry mass of the aerial part, total dry mass, root phosphorus accumulation, plant phosphorus accumulation, phosphorus content in the roots, root phosphorus use efficiency, aerial part phosphorus use efficiency and plant phosphorus use efficiency of arabica coffee genotypes.

For the dry mass of the roots, two groups were formed, in which the cultivars Bourbon Amarelo IAC J10, Topázio MG 1190, MGS Aranãs and Paraíso MG H 419-1 showed an equal behavior and superior to the others. As for the dry mass of the aerial part, there was the formation of three groups, where the cultivars Paraíso MG H 419-1 and Bourbon Amarelo IAC J10 showed an equal behavior and superior to the others. For the total dry mass, there were also the formation of three groups, where the cultivars Bourbon Amarelo IAC J10 and Paraíso MG H 419-11 showed an equal behavior and superior to the others.

In the root phosphorus accumulation, two groups were formed, in which the cultivars Paraíso MG H 419-1, Bourbon Amarelo IAC J10, Catuaí Vermelho IAC 144, MGS Aranãs, Catiguá MG2 and Topázio MG 1190 showed the same behavior between each other and superior to the others. In the plant phosphorus accumulation, there was also the formation of two groups, in which the cultivars Paraíso MG H 419-1 and Bourbon Amarelo IAC J10 showed an equal behavior and superior to the others.

For the phosphorus content in the roots, two groups were formed, and the cultivars Catiguá MG2, Catuaí Vermelho IAC 144, MGS Ametista, Paraíso MG H 419-1 and Sarchimor MG 8840 showed an equal behavior and superior to the others.

For the root phosphorus use efficiency, two groups were formed, where the cultivars Bourbon Amarelo IAC J10 and Topázio MG 1190 showed an equal behavior and superior to the others. In the aerial part phosphorus use efficiency, two groups were formed, in which the cultivars Bourbon Amarelo IAC J10, MGS Aranãs, MGS Paraíso 2 and Paraíso MG H 419-1 
Table 3: Mean of dry mass of the roots (MSR), dry mass of the aerial part (MSPA), total dry mass (MST), root phosphorus accumulation (APRZ), plant phosphorus accumulation (APPL), phosphorus content in the roots (PRZ), root phosphorus use efficiency (EUPRZ), aerial part phosphorus use efficiency (EUPPA) and plant phosphorus use efficiency (EUPPL) of arabica coffee genotypes.

\begin{tabular}{cccccccccc}
\hline Genotypes & $\begin{array}{c}\text { MSR } \\
(\mathrm{g})\end{array}$ & $\begin{array}{c}\text { MSPA } \\
(\mathrm{g})\end{array}$ & $\begin{array}{c}\text { MST } \\
(\mathrm{g})\end{array}$ & $\begin{array}{c}\text { APRZ } \\
(\mathrm{mg})\end{array}$ & $\begin{array}{c}\text { APPL } \\
(\mathrm{mg})\end{array}$ & $\begin{array}{c}\text { PRZ } \\
\left(\mathrm{g} \mathrm{kg}^{-1}\right)\end{array}$ & $\begin{array}{c}\text { EUPRZ } \\
\left(\mathrm{g}^{2} \mathrm{mg}^{-1}\right)\end{array}$ & $\begin{array}{c}\text { EUPPA } \\
\left(\mathrm{g}^{2} \mathrm{mg}^{-1}\right)\end{array}$ & $\begin{array}{c}\text { EUPPL } \\
\left(\mathrm{g}^{2} \mathrm{mg}^{-1}\right)\end{array}$ \\
\hline Bourbon Amarelo IAC J10 & $32.19 \mathrm{a}$ & $39.96 \mathrm{a}$ & $72.15 \mathrm{a}$ & $18.87 \mathrm{a}$ & $62.00 \mathrm{a}$ & $0.58 \mathrm{~b}$ & $19.05 \mathrm{a}$ & $28.92 \mathrm{a}$ & $92.31 \mathrm{a}$ \\
Catiguá MG2 & $20.75 \mathrm{~b}$ & $29.41 \mathrm{c}$ & $50.16 \mathrm{c}$ & $16.05 \mathrm{a}$ & $50.75 \mathrm{~b}$ & $0.80 \mathrm{a}$ & $11.86 \mathrm{~b}$ & $20.99 \mathrm{~b}$ & $63.17 \mathrm{~b}$ \\
Catuaí Vermelho IAC 144 & $23.19 \mathrm{~b}$ & $29.12 \mathrm{c}$ & $52.31 \mathrm{c}$ & $16.40 \mathrm{a}$ & $43.91 \mathrm{~b}$ & $0.66 \mathrm{a}$ & $13.08 \mathrm{~b}$ & $23.36 \mathrm{~b}$ & $69.77 \mathrm{~b}$ \\
MGS Ametista & $18.82 \mathrm{~b}$ & $26.22 \mathrm{c}$ & $45.05 \mathrm{c}$ & $13.66 \mathrm{~b}$ & $45.70 \mathrm{~b}$ & $0.71 \mathrm{a}$ & $8.38 \mathrm{~b}$ & $18.83 \mathrm{~b}$ & $51.20 \mathrm{~b}$ \\
MGS Aranãs & $25.99 \mathrm{a}$ & $34.89 \mathrm{~b}$ & $60.89 \mathrm{~b}$ & $16.26 \mathrm{a}$ & $48.59 \mathrm{~b}$ & $0.63 \mathrm{~b}$ & $14.76 \mathrm{~b}$ & $27.12 \mathrm{a}$ & $81.36 \mathrm{a}$ \\
MGS Paraíso 2 & $23.23 \mathrm{~b}$ & $35.03 \mathrm{~b}$ & $58.26 \mathrm{~b}$ & $13.25 \mathrm{~b}$ & $47.14 \mathrm{~b}$ & $0.56 \mathrm{~b}$ & $13.77 \mathrm{~b}$ & $29.94 \mathrm{a}$ & $83.72 \mathrm{a}$ \\
Paraíso MG H 419-1 & $25.87 \mathrm{a}$ & $43.33 \mathrm{a}$ & $69.20 \mathrm{a}$ & $19.80 \mathrm{a}$ & $65.09 \mathrm{a}$ & $0.76 \mathrm{a}$ & $11.96 \mathrm{~b}$ & $32.80 \mathrm{a}$ & $82.56 \mathrm{a}$ \\
H 6-47-10 pl. 3 & $20.68 \mathrm{~b}$ & $27.73 \mathrm{c}$ & $48.41 \mathrm{c}$ & $10.21 \mathrm{~b}$ & $39.40 \mathrm{~b}$ & $0.52 \mathrm{~b}$ & $12.52 \mathrm{~b}$ & $21.18 \mathrm{~b}$ & $64.85 \mathrm{~b}$ \\
Sarchimor MG 8840 & $17.96 \mathrm{~b}$ & $29.90 \mathrm{c}$ & $47.86 \mathrm{c}$ & $12.78 \mathrm{~b}$ & $49.32 \mathrm{~b}$ & $0.67 \mathrm{a}$ & $7.72 \mathrm{~b}$ & $21.34 \mathrm{~b}$ & $54.68 \mathrm{~b}$ \\
Topázio MG 1190 & $30.61 \mathrm{a}$ & $28.97 \mathrm{c}$ & $59.58 \mathrm{~b}$ & $15.85 \mathrm{a}$ & $45.29 \mathrm{~b}$ & $0.51 \mathrm{~b}$ & $24.66 \mathrm{a}$ & $20.85 \mathrm{~b}$ & $90.05 \mathrm{a}$ \\
\hline
\end{tabular}

Mean followed by the same letter in the column do not differ statistically, at $5 \%$ significance, by the Scott-Knott cluster test.

showed an equal behavior and superior to the others. For the plant phosphorus use efficiency, two groups were formed, in which the cultivars Bourbon Amarelo IAC J10, MGS Aranãs, MGS Paraíso 2, Paraíso MG H 419-1 and Topázio MG 1190 showed an equal behavior between each other and superior to the others.

Other efficiency indexes that corroborate the selection and classification of arabica coffee genotypes regarding their nutritional efficiency are shown in Table 4.

The graphical representation of the data in Table 4 is shown in figure 1, as proposed by Gerloff (1977). The cultivars Bourbon Amarelo IAC J10 and MGS Aranãs were classified as efficient and responsive (ER), that is, they are efficient in the production of dry mass under conditions of low phosphorus supply and respond in increment of dry mass if phosphate fertilization is provided. The cultivars Paraíso MG H 419-1, Topázio MG 1190 and MGS Paraíso 2 were classified as efficient and unresponsive (ENR), that is, they are efficient in the production of dry mass under conditions of low phosphorus supply, but do not respond in increment of dry mass if phosphate fertilization is provided. Progeny H 6-47-10 pl. 3 and the cultivar Catuaí Vermelho IAC 144 were classified as inefficient and responsive (NER), that is, they are not efficient in the production of dry mass under conditions of low phosphorus supply but respond in increment of dry mass if phosphate fertilization is provided. The cultivars Catiguá MG2, MGS Ametista and Sarchimor MG 8840 were classified as inefficient and unresponsive (NENR), that is, they are not efficient in the production of dry mass under conditions of low phosphorus supply and do not respond in increment of dry mass if phosphate fertilization is provided.
According to the principal components analysis, there was variability between treatments. Table 5 shows the correlation of the evaluated characters with the first and second principal components. The contribution of characters to treatment discrimination is related to higher absolute values in components 1 and 2 .

Table 4: Total dry mass without phosphate fertilization (MSTAP) and agronomic phosphorus use efficiency (EAUP) of arabica coffee genotypes in their respective groups: ER (efficient and responsive), ENR (efficient and unresponsive), NER (inefficient and responsive) and NENR (inefficient and unresponsive).

\begin{tabular}{ccc}
\hline Genotypes & MSTAP $(\mathrm{g})$ & EAUP $\left(\mathrm{g} \mathrm{mg}^{-1} \mathrm{P}\right)$ \\
\hline ER & & \\
Bourbon Amarelo IAC J10 & 56.84 & 0.97 \\
MGS Aranãs & 52.14 & 0.63 \\
ENR & & \\
Paraíso MG H 419-1 & 67.38 & 0.22 \\
Topázio MG 1190 & 52.71 & 0.42 \\
MGS Paraíso 2 & 51.82 & 0.45 \\
NER & & \\
H 6-47-10 pl. 3 & 44.35 & 0.76 \\
Catuaí Vermelho IAC 144 & 41.52 & 0.60 \\
NENR & & \\
Catiguá MG2 & 42.56 & 0.28 \\
MGS Ametista & 39.08 & 0.46 \\
Sarchimor MG 8840 & 38.77 & 0.46 \\
Mean & 48.72 & 0.52 \\
\hline
\end{tabular}

Mean are used as a reference parameter for genotype classification, as shown in Figure 1. 


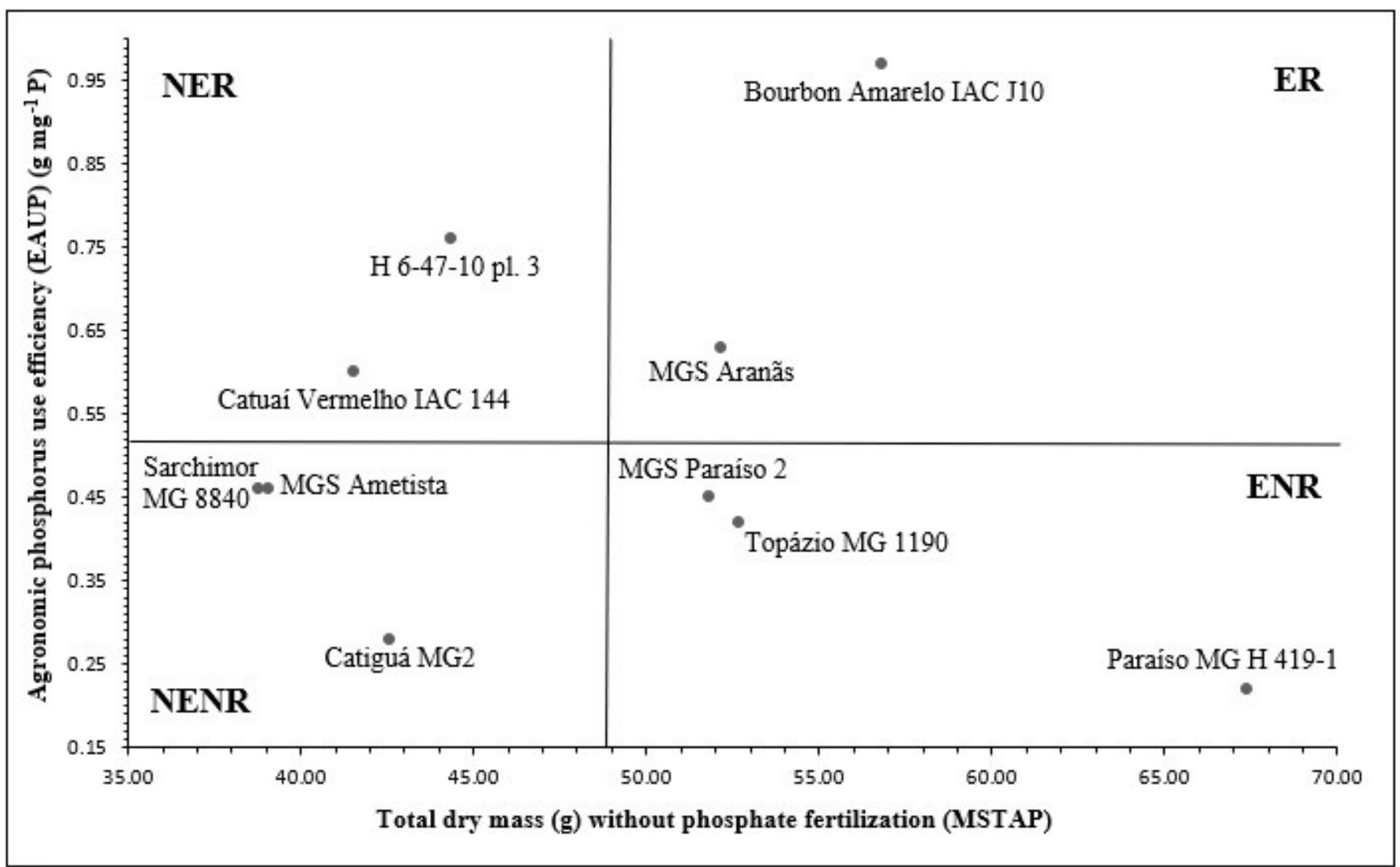

Figure 1: Relationship between total dry mass without phosphate fertilization (MSTAP) and agronomic phosphorus use efficiency (EAUP) of arabica coffee genotypes in their respective groups: ER (efficient and responsive), ENR (efficient and unresponsive), NER (inefficient and responsive) and NENR (inefficient and unresponsive).

For the principal component 1 , the characters that most contributed to the variability of the treatments were: total dry mass (MST), plant phosphorus use efficiency (EUPPL) and dry mass of the aerial part (MSPA). The characters that had the highest correlation with principal component 2 were: phosphorus uptake efficiency (EAP), phosphorus available in the soil (PDI) and aerial part phosphorus accumulation (APPA) (Table 5).

For the characters evaluated, the first two principal components explained $76.37 \%$ of the total data variation, with the first principal component corresponding to $44.91 \%$ of the data variation and the second principal component with 31.46\%. The genotypes Paraíso MG H 419-1 and Bourbon Amarelo IAC J10 differed from the others by presenting values above the mean for the characters: dry mass of the aerial part (MSPA), total dry mass (MST), root phosphorus accumulation (APRZ), aerial part phosphorus accumulation (APPA), plant phosphorus accumulation (APPL) and aerial part phosphorus use efficiency (EUPPA). The Topázio MG 1190 genotype differed from the others by values above the mean for the characters: dry mass of the roots (MSR), efficiency of use of phosphorus in the root (EUPRZ) and plant phosphorus use efficiency (EUPPL) (Figure 2, Table 2 and 3).

\section{DISCUSSION}

In a study conducted by Neto et al. (2016), in which the authors studied coffee cultivars with and without phosphate fertilization, similar results to those found in this work were obtained, that is, the height, dry mass, phosphorus content in the aerial part of the plant and the content of phosphorus in the plant root showed superior results where there was phosphate fertilization.

The acquisition of nutrients depends on the efficiency of the uptake mechanisms and the volume of soil explored by the roots and can be assessed by the efficiency of uptake and root production (Amaral et al., 2011).

This behavior of the coffee tree being more efficient in using phosphorus even in conditions of low availability of this nutrient was also found by Neto et al. (2016). Phosphorus plays a fundamental role in plant metabolism. The phosphorus plays a significant role in many metabolic processes, such as energy generation, nucleic acid synthesis, respiration, membrane synthesis and its integrity, photosynthesis, activation, or inactivation of enzymes, signaling, and carbohydrate metabolism (Zhang; Liao; Lucas, 2014). Due to the importance of phosphorus in the metabolism of plants, it is expected that its limitation can affect the development, mainly of the root system. 
Table 5: Correlation between the evaluated characters and the principal components in arabica coffee genotypes under absence or presence of phosphate fertilization.

\begin{tabular}{ccc}
\hline Feature & Component 1 & Component 2 \\
\hline Dry mass of the roots (MSR) & 0.34 & 0.17 \\
Dry mass of the aerial part (MSPA) & 0.35 & 0.17 \\
Total dry mass (MST) & 0.39 & 0.01 \\
Root phosphorus accumulation (APRZ) & 0.33 & 0.04 \\
Aerial part phosphorus accumulation (APPA) & 0.26 & 0.35 \\
Plant phosphorus accumulation (APPL) & 0.31 & 0.27 \\
Phosphorus available in the soil (PDI) & 0.01 & 0.36 \\
Phosphorus resin (PRS) & -0.06 & 0.32 \\
Remaining phosphorus in the soil (PRM) & -0.10 & 0.31 \\
Phosphorus uptake efficiency (EAP) & -0.04 & 0.44 \\
Phosphorus translocation efficiency (ETP) & -0.13 & 0.25 \\
Root phosphorus use efficiency (EUPRZ) & 0.23 & -0.30 \\
Aerial part phosphorus use efficiency (EUPPA) & 0.32 & 0.11 \\
Plant phosphorus use efficiency (EUPPL) & 0.35 & -0.16 \\
\hline
\end{tabular}

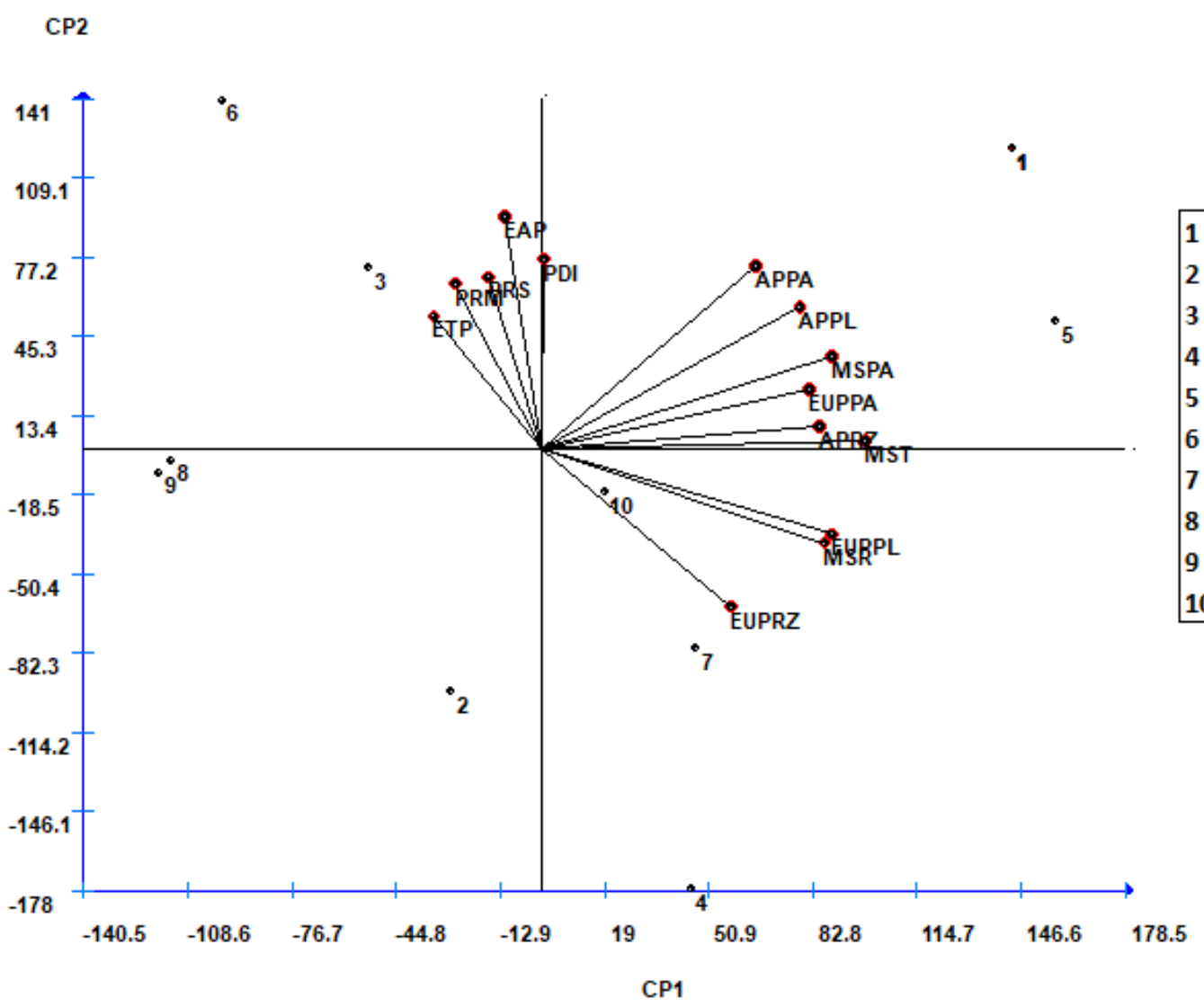

Figure 2: Dispersion of arabica coffee genotypes and spatial projection of the character vectors in relation to the first two principal components.

In relation to all genotypes, a highlight, however negative, is that the progeny $\mathrm{H}$ 6-47-10 pl. 3 showed inferior behavior to the other genotypes in all evaluated characteristics.
Studies such as those by Carvalho et al. (2010), Ferreira et al. (2014) and Neto et al. (2016) demonstrated that the various coffee cultivars currently available show different 
agronomic behavior, and the evaluation of different parameters helps in the classification of these cultivars regarding their performance. The term nutritional efficiency can be expressed as the relationship between the production obtained and the inputs applied to obtain this production, that is, this mean that nutritional efficiency is the amount of dry mass or grains produced per unit of applied nutrient (Fageria, 1998).

According to Camargo et al. (2004), a genotype with high nutritional efficiency is a plant highly efficient in the use of nutrients, even in adverse conditions, such as low soil fertility, few water resources, or excess salts, and may be the way to obtain greater productivity, or even in the selection of superior genetic material.

In a study conducted by Neto et al. (2016), the authors found results divergent from that of this study, and for the cultivars Bourbon Amarelo IAC J19 and Catuaí Vermelho IAC 144 the classification was as efficient and unresponsive (ENR).

The close relationship between the different efficiency indexes adopted can be observed when we verify that the cultivars that were agronomically efficient (responsive or not to the applied phosphorus) are the same ones that were efficient in the use of phosphorus in the plant, and the behavior with the inefficient ones (also responsive or not to applied phosphorus) was the same (Table 3). This emphasizes that these indexes are safe and concise in discriminating efficiency.

The cultivars of the "Bourbon" group are classified as tall for plant height, a characteristic that influenced the results found for the Bourbon Amarelo IAC J10, the only genotype of the experiment classified as tall.

The cultivar Bourbon Amarelo IAC J10 is notoriously recognized for its predisposition to superior quality beverages, however it is also characterized by having low vegetative vigor and high susceptibility to the main disease of the crop, coffee leaf rust, suffering with intense depletion, if it has inadequate nutrition and disease control measures are not adopted. In this case, in relation to phosphate nutrition, it is evident that the cultivar Bourbon Amarelo IAC J10 needs special attention, a behavior that must be extended to the cultivar MGS Aranãs.

The cultivars Paraíso MG H 419-1, Topázio MG 1190 and MGS Paraíso 2 were classified as efficient in the production of dry mass and unresponsive to the supply of phosphorus, being able to be used in soils with a lower phosphate fertility or under cultivation conditions where the supply of phosphorus via fertilization is lower than the level required by cultivars that are responsive to its supply.

For more sustentaible cultivations, preference should be given to highly efficient cultivars in nutrient use, however, with low nutrient requirement. On the other hand, there is no guarantee that these cultivars are highly productive (Kist et al., 2015). One of the great challenges of modern agriculture is the use of a strategy for adapting plants to low fertility soils. In these cases, there are two alternatives: to increase soil fertility with correctives and fertilizers, or to use nutritionally efficient cultivars (Pozza et al., 2009).

Other authors, such as Amaral et al. (2011), Neto et al. (2016) and Pozza et al. (2009) also studied the phosphate efficiency in coffee trees, these authors saw that there are significant differences between cultivars and between species (Coffea arabica and Coffea canephora).

Determining nutritional efficiencies in field-level experiments provides more information on the behavior of different genotypes. Other agronomic parameters, such as productivity, can also be used to assess nutritional efficiency, corroborating the data obtained in greenhouse experiments.

\section{CONCLUSIONS}

The cultivars Catiguá MG2, MGS Ametista and Sarchimor MG 8840 are neither efficient nor responsive to phosphate fertilization.

The progeny H 6-47-10 pl. 3 and the cultivar Catuai Vermelho IAC 144 are not efficient but are responsive to phosphate fertilization.

The cultivars Paraíso MG H 419-1, Topázio MG 1190 and MGS Paraíso 2 are efficient but are not responsive to phosphate fertilization.

The cultivars Bourbon Amarelo IAC J10 and MGS Aranãs are efficient and responsive to phosphate fertilization.

\section{ACKNOWLEDGMENTS}

To FAPEMIG and CNPq for financial support. To Consórcio Pesquisa Café (Embrapa/Café) for financing the research project.

To CAPES (Coordenação de Aperfeiçoamento de Pessoal de Nível Superior) for granting the scholarship. "This work was carried out with the support of the Coordenação de Aperfeiçoamento de Pessoal de Nível Superior - Brasil (CAPES) - Financing Code 001”.

\section{REFERENCES}

ALVAREZ, V. et al. Determinação e uso do fósforo remanescente. Boletim Informativo da Sociedade Brasileira de Ciência Solo, 25:21-32, 2000.

AMARAL, J. F. T. et al. Eficiência de utilização de nutrientes por cultivares de cafeeiro. Ciência Rural, 41(4):621-629, 2011.

CAMARGO, M. L. P. et al. Considerações sobre eficiência nutricional em Eucalyptus. Científica, 32(2):191-196, 2004. 
CARVALHO, A. M. et al. Correlação entre crescimento e produtividade de cultivares de café em diferentes regiões de Minas Gerais, Brasil. Pesquisa Agropecuária Brasileira, 45(3):269-275, 2010.

CRUZ, C. D. Genes: A software package for analysis in experimental statistics and quantitative genetics. Acta Scientiarum. Agronomy, 35(3):271-276, 2013.

EMPRESA BRASILEIRA DE PESQUISA AGROPECUÁRIA - EMBRAPA. Sistema Brasileiro de Classificação de Solos. 5. ed. rev. e ampl. Brasília, DF: Embrapa, 2018. 356p.

FAGERIA, N. K. Otimização da eficiência nutricional na produção das culturas. Revista Brasileira de Engenharia Agrícola e Ambiental, 2(1):6-16, 1998.

FERREIRA, D. F. Estatística multivariada. 2. edi. rev. ampl. Lavras: Ed. UFLA, 2011. 676p.

FERREIRA, A. D. et al. Crescimento de cafeeiros enxertados cultivados em solução nutritiva. Coffee Science, 9(3):312-318, 2014.

GERLOFF, G. C. Plant efficiencies in the use of N, P and K. In: WRIGHT, M. J. (Ed.). Plant adaptation to mineral stress in problem soils. New York: Cornell University Press, p.161-174, 1977.

KIST, V. et al. Nutrient use efficiency in sugarcane cultivars. Científica, 43(2):117-125, 2015.

LI, B.; MCKEAND, S. E.; ALLEN, H. L. Genetic variation in nitrogen use efficiency of loblolly pine seedlings. Forest Science, 37(2):613-626, 1991.

NOVAIS, R. F.; NEVES, J. C. L.; BARROS, N. F. Ensaio em ambiente controlado. In: OLIVEIRA, A. J. et al. (Coord.). Métodos de pesquisa em fertilidade do solo. Brasília: Embrapa-SEA, p.189-253, 1991.

NOVAIS, R. F.; SMYTH, T. J. Fósforo em solo e planta em condições tropicais. Viçosa: Ed. UFV/DPS, 1999. 399p.
OLIVEIRA, I. P. et al. Avaliação de cultivares de feijão quanto à eficiência no uso do fósforo. Pesquisa Agropecuária Brasileira, 21(1):39-45, 1987.

NETO, A. P. et al. Analysis of phosphorus use efficiency traits in Coffea genotypes reveals Coffea arabica and Coffea canephora have contrasting phosphorus uptake and utilization efficiencies. Frontiers in Plant Science, 7:e408, 2016.

POZZA, A. A. A. et al. Suprimento do silicato de cálcio e a eficiência nutricional de variedades de cafeeiro. Revista Brasileia de Ciência do Solo, 33(6):1705-1714, 2009.

SARRUGE, J. R.; HAAG, H. P. Análise química das plantas. Piracicaba: Ed. ESALQ, 1974. 56p.

SIDDIQI, M. Y.; GLASS, A. D. M. Utilization index: A modified approach to the estimation and comparison of nutrient utilization efficiency in plants. Journal of Plant Nutrition, 4(3):289-302, 1981.

SWIADER, J. M.; CHYAN, Y.; FREIJI, F. G. Genotypic differences in nitrate uptake and utilization efficiency in pumpkin hybrids. Journal of Plant Nutrition, 17(10):1687-1699, 1994.

TEDESCO, M. J. et al. Análise de solo, plantas e outros materiais. 2. ed. Porto Alegre: Ed. Universidade Federal do Rio Grande do Sul, 1995. 147p.

TOMAZ, M. A. et al. Eficiência de absorção e utilização de boro, zinco, cobre e manganês em mudas enxertadas de cafeeiro. Ceres, 58(1):108-114, 2011.

VAN RAIJ, B.; QUAGGIO, J. A. Métodos de análises de solos para fins de fertilidade. Campinas: Instituto Agronômico, 1983. 31p.

ZHANG, Z.; LIAO, H.; LUCAS, W. J. Molecular mechanisms underlying phosphate sensing, signaling, and adaptation in plants. Journal of Integrative Plant Biology, 56:192-220, 2014. 